University of Nebraska - Lincoln

DigitalCommons@University of Nebraska - Lincoln

PreColumbian Textile Conference VIII /

Jornadas de Textiles PreColombinos VIII (2019)

Centre for Textile Research

$6-2020$

\title{
El tapiz colonial con tocapus del Museo Nacional de Arqueología, Antropología e Historia del Perú
}

Mónica Solórzano Gonzales

Follow this and additional works at: https://digitalcommons.unl.edu/pctviii

Part of the Art and Materials Conservation Commons, Fiber, Textile, and Weaving Arts Commons, Indigenous Studies Commons, Latin American Languages and Societies Commons, Museum Studies Commons, and the Other History of Art, Architecture, and Archaeology Commons

This Article is brought to you for free and open access by the Centre for Textile Research at DigitalCommons@University of Nebraska - Lincoln. It has been accepted for inclusion in PreColumbian Textile Conference VIII / Jornadas de Textiles PreColombinos VIII (2019) by an authorized administrator of DigitalCommons@University of Nebraska - Lincoln. 


\title{
El tapiz colonial con tocapus del Museo Nacional de Arqueología, Antropología e Historia del Perú
}

\author{
Mg. Mónica Solórzano Gonzales \\ Universidad Nacional Mayor de San Marcos \\ msolorzanog@unmsm.edu.pe
}

\begin{abstract}
Resumen
Se estudia en este texto un extraordinario tapiz que resalta por una decoración que combina símbolos incaicos, con aspecto de tocapus, con una cruz cristiana. Forma parte de una investigación mayor dedicada al tapiz andino colonial próxima a divulgarse. Actualmente, no se conoce otro ejemplar semejante en el Perú ni en el extranjero y probablemente se trata de uno de los tapices coloniales más antiguos. Tuvimos la fortuna de darlo a conocer en los seminarios del Doctorado del Programa de Estudios Andinos de la Pontificia Universidad Católica del Perú y en otros eventos desde el año 2014.

Se halla en el depósito de textiles del Museo Nacional de Arqueología, Antropología e Historia del Perú y no cuenta con datos de contexto. Está tejido con técnicas y fibras andinas tradicionales (algodón y camélido). Sobresalen los colores contrastantes y principalmente el diseño híbrido en el que las formas geométricas y estilizadas del lenguaje gráfico inca aparecen junto a un símbolo católico. Analizamos tanto la iconografía, como la técnica del tejido, los usos y posibles propietarios.

La pieza muestra una continuidad del tejido andino ancestral pues varias características estructurales son parte del patrón de estandarización del tejido impuesto por el Estado inca para la elaboración de los uncus destinados a las élites. Ello revela que el tejido de cumbi (tejido fino de los incas) trascendió a los convulsos momentos de la conquista y pervivió en formato y función distintos.
\end{abstract}

Palabras claves: Tapiz colonial, tocapu, catecismo cristiano, sincretismo.

\begin{abstract}
We study here an extraordinary tapestry, unusual due to a decorative program that combines Inca symbols resembling tocapus with a Christian cross. It is part of a larger investigation dedicated to colonial Andean tapestry that is soon to be published. No other similar specimen is known in Peru or abroad and it is probably one of the oldest known colonial tapestry. We have been fortunate to first present it in the seminars of the doctoral program in Andean Studies of the Pontifical Catholic University of Peru and in other events since 2014.

It is located in the textile storage facility of the National Museum of Archeology, Anthropology and History of Peru and has no contextual data. It was woven with Andean traditional techniques and fibers (cotton and camelid). The contrasting colors stand out and particularly the hybrid design in which the geometric and stylized elements of the Inca graphic language appear next to a Catholic symbol. We analyze the iconography as well as the technique of the fabric, its uses and possible owners.

The tapestry shows continuity in the ancient Andean textiles as several structural characteristics are part of the policy of standardization of weaving imposed by the Inca State for the elaboration of uncu tunics for the elite men. This reveals that cumbi fabric (fine Inca cloth) transcended the convulsive first moments of the conquest and survived in a different format and function.
\end{abstract}

Keywords: Colonial tapestry, tuqapu, Christian catechism, syncretism.

DOI: $10.32873 /$ unl.dc.zea.1211

Published in PreColumbian Textile Conference VIII / Jornadas de Textiles PreColombinos VIII, ed. Lena Bjerregaard and Ann Peters

(Lincoln, NE: Zea Books, 2020). https://digitalcommons.unl.edu/zeabook/ 


\section{Résumé}

Nous étudions dans cet article un extraordinaire tapis qui attire l'attention par sa décoration combinant des symboles incas semblables aux tocapus, avec la croix chrétienne. Ce dernier fait partie d'une recherche majeure dédiée aux tapis andins coloniaux à paraître prochainement. Nous ne connaissons pas un autre exemplaire semblable au Pérou ni à l'étranger et probablement il s'agit du tapis colonial le plus ancien. Nous avons eu la chance de le faire connaître au cours des séminaires de Doctorat du Programme d'Etudes Andines de l’Université Pontificale Catholique du Pérou et dans d'autres évènements depuis l'année 2014 .

Il se trouve dans le dépôt textile du Musée National d'Archéologie, Anthropologie et Histoire du Pérou et mous ne possédons pas d'information sur son contexte. Il est tissé avec des techniques et des fibres (de coton et de camélidés) andines traditionnelles. Les colorants contrastants, et principalement le motif hybride, dans lequel se démarquent les formes géométriques et stylisées du langage graphique inca apparaissent près d'un symbole catholique. Nous analysons tant l'iconographie que la technique du tissu, ses usages et ses possibles propriétaires.

Le tapis montre une continuité du tissu andin millénaire étant donné que plusieurs caractéristiques structurelles font partie du modèle de standardisation du tissu imposé par l'Etat inca pour l'élaboration des uncu destinés aux élites masculines. Cela révèle que le tissu cumbi (tissu fin des incas) a dépassé les moments mouvementés de la Conquête et a perduré dans des formats et des fonctions différentes.

Mots-clés: Tapis colonial, tocapu, catéchisme chrétien, syncrétisme.

\section{Introducción}

En noviembre del 2013, cuando se inició la investigación sobre tapices coloniales, se halló un extraordinario ejemplar hasta entonces desconocido entre los estudiosos. ${ }^{1}$ La desazón inicial experimentada ante el reducido número de la colección fue desapareciendo con cada centímetro desplegado de la pieza que sorprendía por su apariencia inca, su tamaño, la fineza del tejido, el color y la cruz cristiana en el centro. ${ }^{2}$ El tapiz que está signado con el código de registro textil N. o 7788, (Figura 1) se ubica en el depósito del área de textiles del Museo Nacional de Arqueología, Antropología e Historia del Perú (MNAAHP) y es, posiblemente, el único en su tipo del grupo de tapices coloniales conocidos en Perú. No se sabe cómo llegó al museo, pero se considera que tal vez fue decomisado o que perteneció al grupo de piezas que Julio C. Tello entregó al museo que dirigió desde su fundación ${ }^{3}$. Lo cierto es que para la década de los ochenta ya se encontraba en el departamento de textiles, según consta en la ficha técnica.

Ante la falta de información sobre los propietarios, la antigüedad y el lugar de procedencia del tapiz, fue necesario establecer una cronología aproximada, identificar el lugar donde fue elaborado, determinar quiénes fueron los propietarios originales y las posibles funciones.

Se parte del análisis del objeto textil, observando las características del hilado en ambos elementos estructurales (trama y urdimbre), la torsión de los hilos, la cantidad de hilos por centímetro, el tipo de ligamento, entre otros. Estos datos se comparan con los de los uncus imperiales para establecer analogías y cambios. También se analiza la iconografía y los significados de los principales motivos ornamentales, que contribuye a determinar su procedencia y su función. Además, importante data aporta el estado de conservación, pues los tipos de deterioro muestran indicios del uso.

\section{Iconografía y principales motivos decorativos}

El diseño del textil está organizado en dos áreas enmarcadas por gruesas líneas de color rojo carmín4: el campo central (A), que resalta por estar cubierto de tocapus de colores intensos y contrastantes, es el fondo de una gran cruz de

1. Un avance del presente capítulo se publicó en Solórzano, M. (2016). El tapiz andino de transición. Estudio iconográfico y técnico. Escritura y Pensamiento, XIX (39), 327-353.

2. La experiencia fue compartida por las conservadoras del museo M. Medina y M. de la Cruz. Posteriormente, junto con otros investigadores nos encargamos de darla a conocer en los seminarios del doctorado del Programa de Estudios Andinos de la PUCP en Lima y Pisac, Cusco, durante los años 2014 y 2015 y en el 56. ${ }^{\circ}$ Congreso Internacional de Americanistas llevado a cabo en Salamanca, España, el año 2018.

3. El personal del museo realiza la organización del material de archivo que probablemente permita conocer la procedencia del bien.

4. El rojo carmín es producido por el insecto Dactilopius coccus (cochinilla, macnu en quechua) que se alimenta del cactus del género Opuntia entre ellos el Nopalea coccinellifera. El estudio de Noemí Rosario (1999) demostró que en los Andes se empleó la cochinilla para teñir fibras textiles desde los Huari y que durante el Periodo Intermedio tardío se generaliza su uso especialmente en los textiles Chancay e Inca, ante la desaparición de otros materiales tintóreos rojos. La autora llegó a esa conclusión a través del análisis de fibras de 42 tejidos pertenecientes a culturas del periodo Intermedio temprano hasta el periodo colonial temprano aplicando la Prueba de Cromatografía Líquida de Alta Resolución (CLAR). 


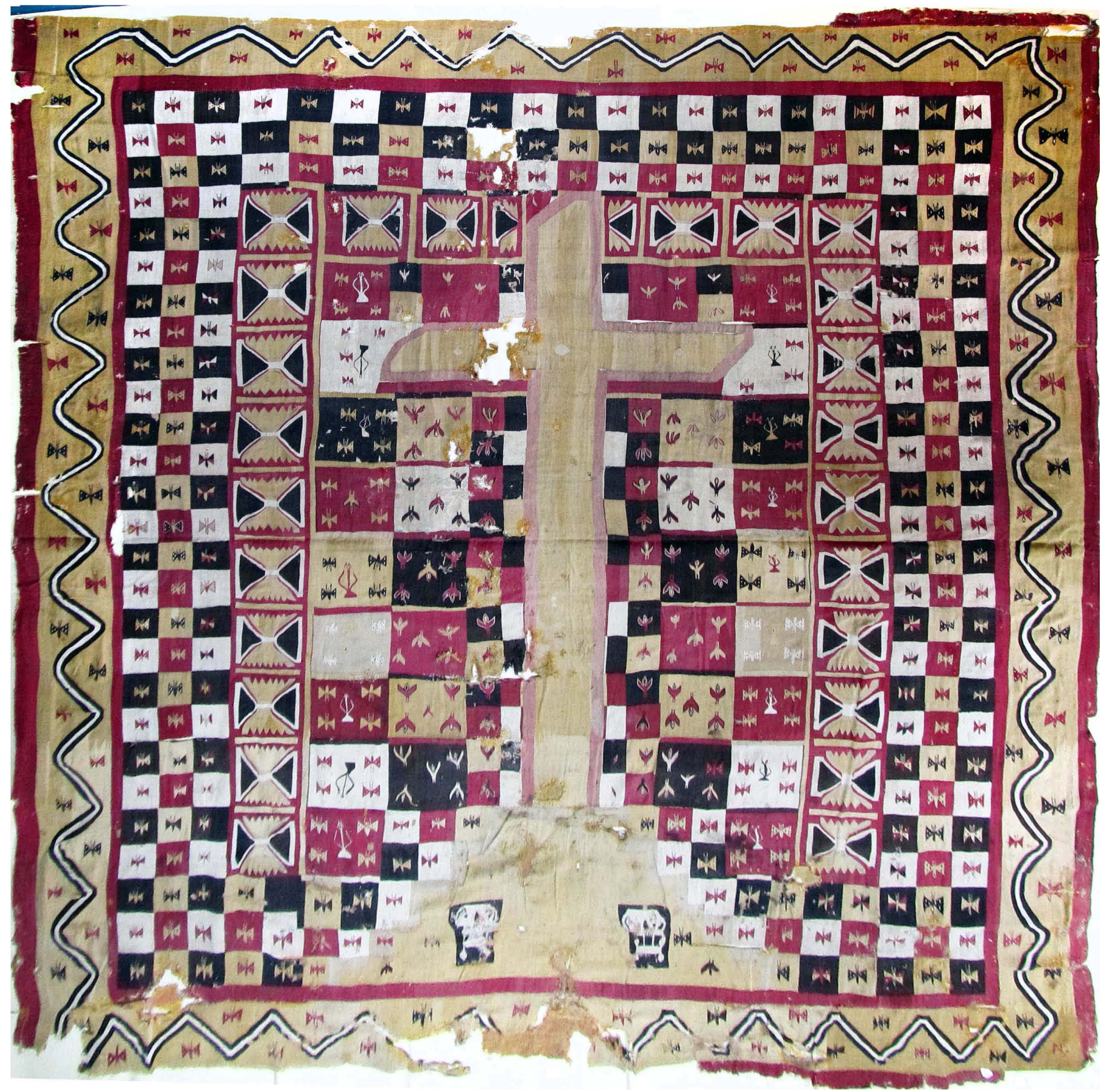

Figura 1. Tapiz colonial con tocapus. Museo Nacional de Arqueología, Antropología e Historia del Perú. R. T. 7788. Fotógrafo: Mónica Solórzano G.

base escalonada ubicada al centro; mientras que la zona (B) la conforman las bandas laterales que fungen de marco con una línea en zigzag continua que recorre sus cuatro lados.

La zona A (Figura 2 y Figura 3), a su vez está dividida en dos por un diseño también cuadrangular de formas estilizadas que se repite formando columnas en ambos lados y en la parte superior, enmarcando la cruz. El sector A1, cercano a la cruz, presenta tocapus grandes, que miden en promedio
$22 \times 20$ centímetros, los cuales forman dos columnas en cada lado de la cruz. Estas últimas presentan dos conjuntos de motivos, que en algunos casos aparecen en el mismo recuadro, agrupados en cinco e insertos en el interior: uno de ellos conformado por figuras ornitomorfas de cabeza alargada y alas desplegadas; el otro, por mariposas estilizadas con alas desplegadas y pequeños puntos como manchas. Un tercer motivo es una especie de tridente que aparece alguna 


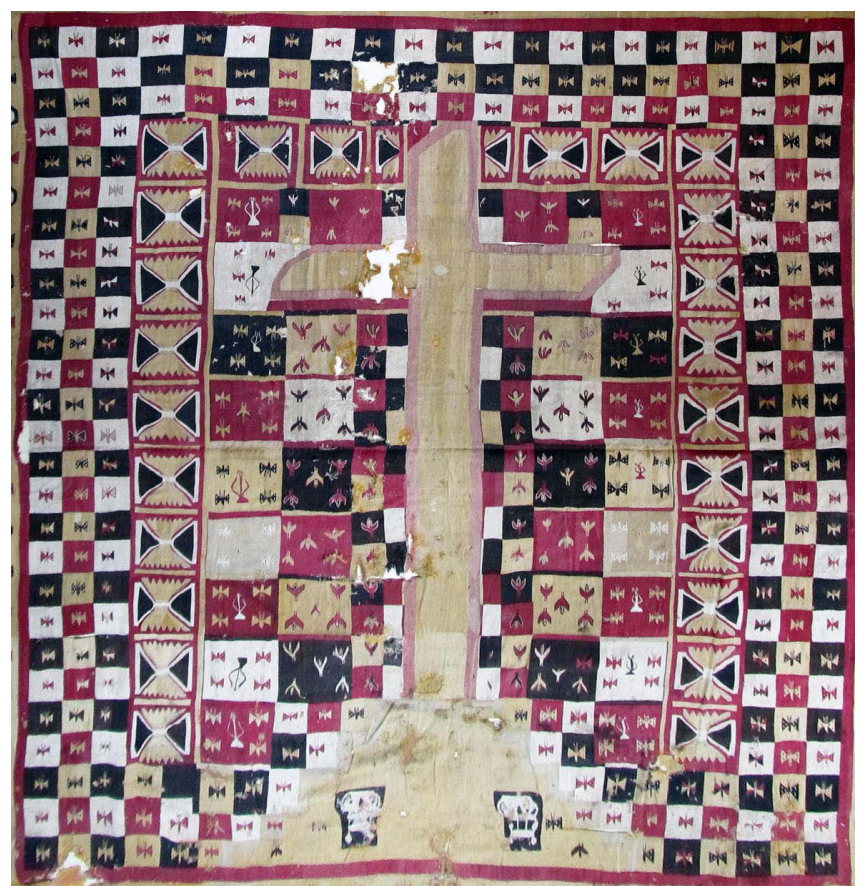

Figura 2. Campo central (zona A). Detalle del tapiz colonial con tocapus.

vez al centro de los recuadros. Dos columnas más de tocapus, de menor tamaño, se hallan junto al mástil de la cruz. Al centro del paño, ocupando todo el sector A1, resalta una gran cruz de tipo latina en color amarillo ocre con tres pequeños rombos blancos ubicados en el centro de la unión de ambos segmentos de la cruz y en los lados del transepto. La base es escalonada y en su interior se hallan dos cráneos sobre fondos rectangulares de color oscuro. Aunque no se trata de las típicas calaveras circulares, no hay duda de tal identificación, pues se reconocen los orificios de los ojos, la nariz, la boca, así como los dientes (Figura 4a y 4b). Una línea de color rosado pálido bordea todo el cuerpo de la cruz.

El sector A2 del campo central está formado por el tocapu más recurrente pues se pueden contar 242 de ellos en esta zona, mide aproximadamente $11 \times 10$ centímetros. Además, presenta una sola mariposa en el interior y forman tres columnas en los tres lados del tapiz en donde los cuatro colores señalados se alternan formando un damero. La primera columna alterna tocapus blancos de mariposas rojas con tocapus negros de mariposas amarillas, en la segunda columna se alternan los recuadros rojos de mariposas amarillas con tocapus amarillos de mariposas negras. En la tercera columna, la más cercana al centro, el color de las mariposas sigue un patrón distinto con mariposas de colores

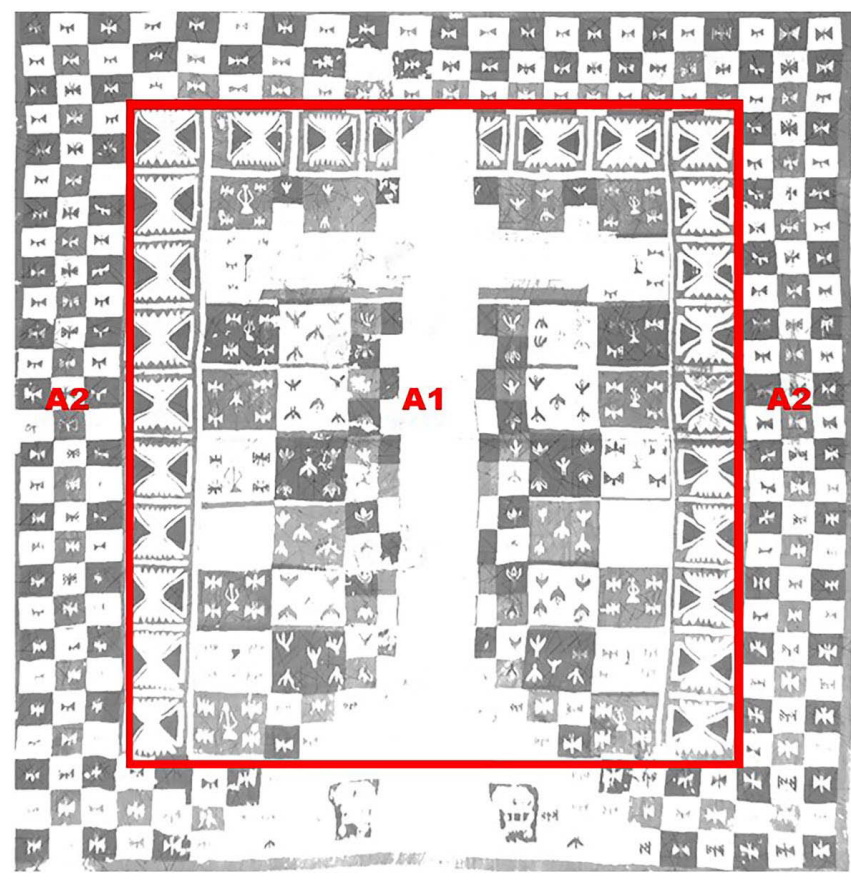

Figura 3. Esquema del campo central con sectores A1 y A2.

amarillo y rojo carmín sobre un fondo negro con variantes y mariposas de color rojo y negro sobre blanco también con variantes, que solo en algunos casos presentan manchas en las alas. Las líneas de color rojo que miden cinco centímetros, aproximadamente, delimitan el sector B donde, sobre el fondo de color amarillo, resalta la gran línea quebrada en blanco y negro/oscuro con 87 mariposas en negro y rojo dispuestas entre las ondas.

Durante la época de los incas, las formas cuadrangulares denominadas tocapus eran símbolo de la élite y su uso en textiles, cerámica, decoración mural y queros era controlado por el Estado. El diccionario de González Holguín define tocapus como «vestimentas con hermosos bordados o paños con bordados entretejidos» (González Holguín, 1608 [1989]: 344). C. Arellano los define como «rectángulos [o cuadrados] provistos de figuras geométricas que se resaltan por medio de colores contrastantes y que se hallan también en diversas vasijas y especialmente en vasos de cerámica, metal o madera, denominados qero [...]» (Arellano:, 1999: $253)^{5}$. Otros autores los identifican como signos o códigos gráficos ordenados y plasmados en los objetos con una intención comunicativa (Cummins, 2014; Frame, 2014; Ziólkowski, 2009; Ziólkowski, Arabas y Szeminski, 2008). Aunque aparecen en objetos diversos, son el elemento principal

5. La autora también señala la posible etimología del término, que derivaría de la sílaba tok y la palabra apu por lo que podría ser traducida como «aquello que destaca al apu, o aquello con que sale el apu» (Arellano, 1999: 253). 


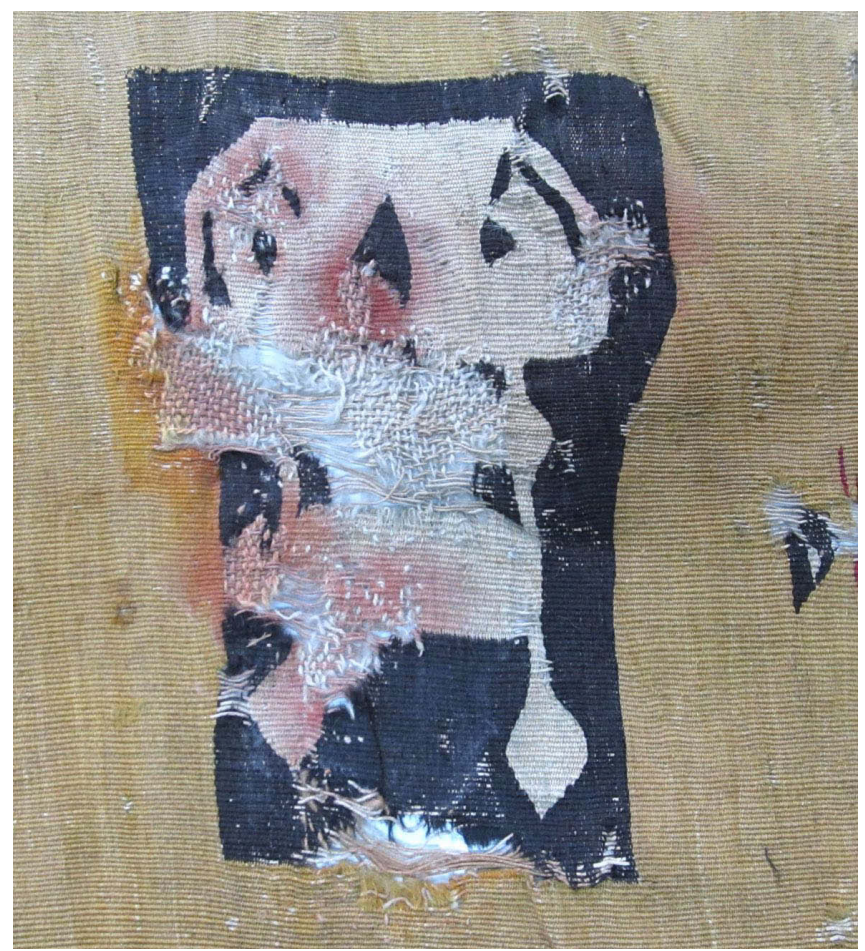

Figura 4a. Calavera en la base de la cruz. Detalle del tapiz colonial con tocapus. Fotógrafo: M. Solórzano G.

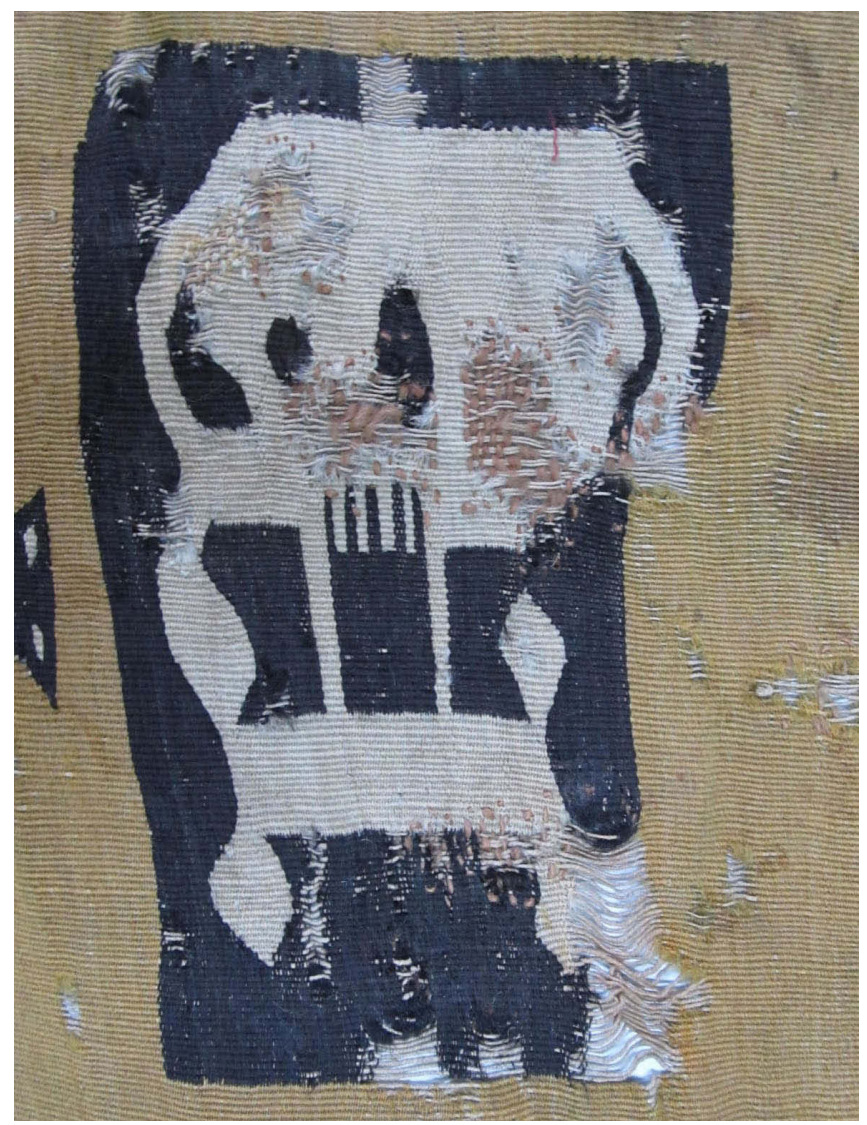

Figura 4b. Calavera en la base de la cruz. Detalle del tapiz colonial con tocapus. Fotógrafo: M. Solórzano G.

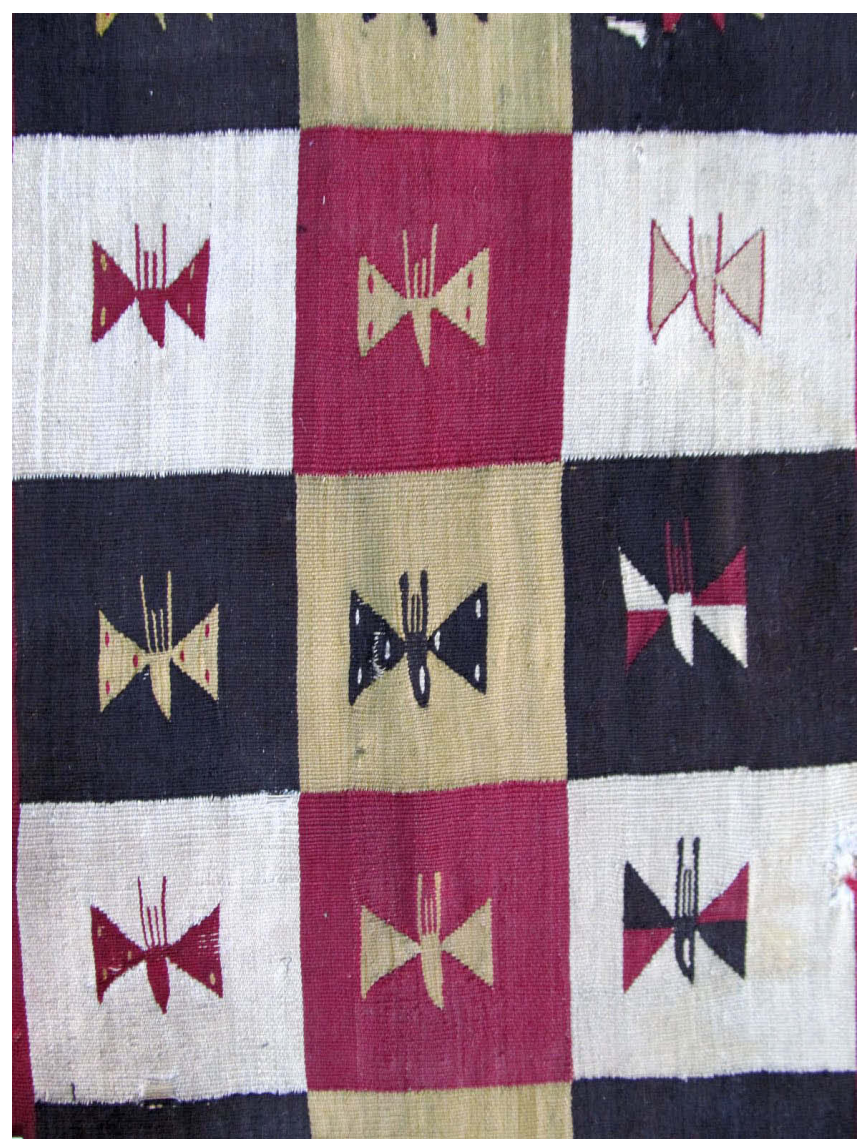

Figura 5. Mariposas en campo central (zona A). Detalle del tapiz colonial con tocapus. Fotógrafo: M. Solórzano G.

en la ornamentación de los uncus ('camisetas' en las crónicas y más recientemente también se denominan 'túnicas'), en tejido de cumbi, reservados al Inca, a las ceremonias religiosas y a los sectores privilegiados y elaborados de acuerdo sistema textil estandarizado impuesto por el Estado. Los colores organizados en pares (amarillo/rojo y blanco/negro) alternados e integrados formando un damero como en el caso del tapiz, aparecen, también, por lo menos, en dos ejemplos de uncus incas identificados y analizados por Mary Frame (2014).

La mariposa, junto con el tocapu, es el motivo más frecuente y aparece hasta cuatrocientas veces en el tejido. En los tocapus pequeños, las mariposas se hallan insertas por unidad al interior de los recuadros (Figura 5); en el tocapu grande, aparecen agrupadas, y se hallan dispersas entre las ondas de la línea en zigzag que circunda el tapiz. Su representación es estilizada, con las alas desplegadas formadas por dos triángulos que se unen a un cuerpo alargado del cual se desprenden cuatro filamentos a modo de antenas en dirección hacia la zona superior del tapiz generalmente.

El motivo conformado por el tocapu con mariposa aparece por lo menos en dos uncus incas que se encuentran en 


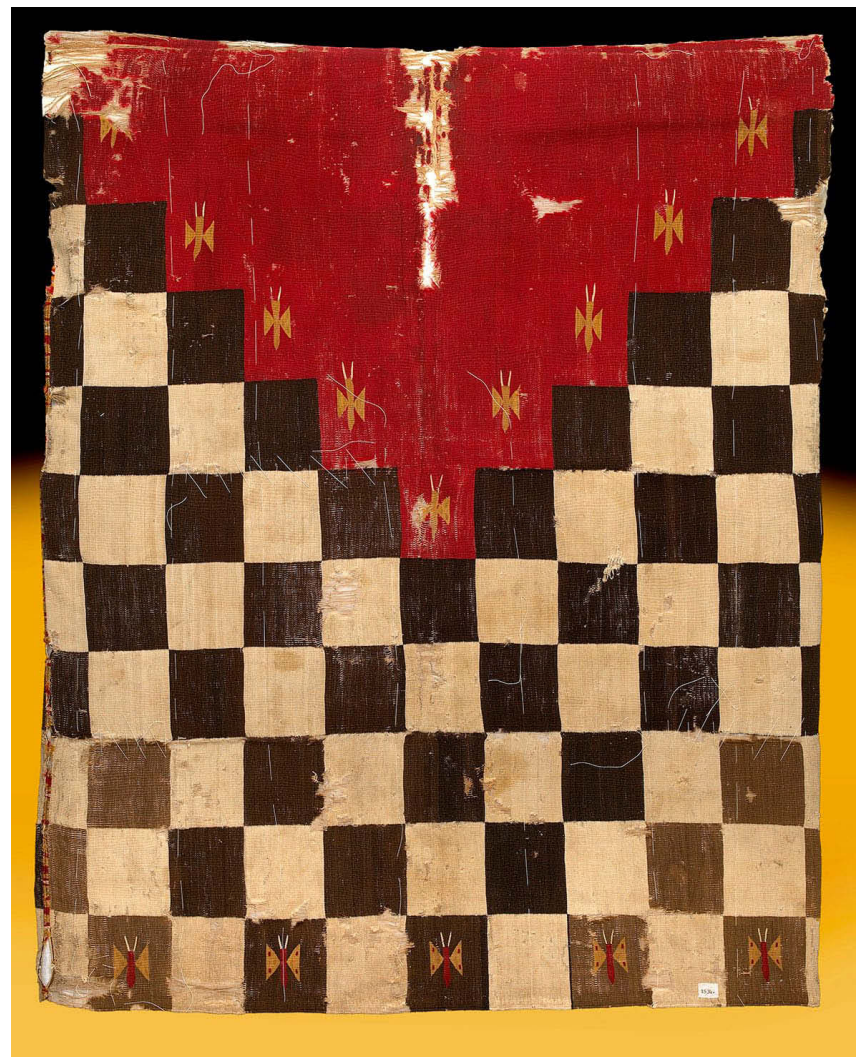

Figura 6. Uncu inca con diseño de damero y mariposas. Field Museum of Natural History, Chicago. Número de catálogo: 1534. nosub \{2\}. Procedencia: Ancón, Lima. Fotógrafo: John Weinstein.

el Field Museum de Chicago (Figura 6) y en una colección privada (Rowe, 1999: 581). Las prendas presentan la zona inferior en recuadros blanco/negro (a modo de un tablero de ajedrez), mientras que la zona superior escalonada es de color rojo. Se cree que estos uncus podrían haber sido usados por guerreros. Al respecto, J. Rowe, siguiendo a Miguel de Estete en Noticia del Perú, sugiere que «eran usadas como uniformes o libreas por la escolta de Atahualpa en Cajamarca en 1532» (Rowe, 1999: 614). Este diseño corresponde al primer patrón de túnicas estandarizadas estudiadas por John Rowe y Ann P. Rowe. Como se puede observar en las imágenes, el diseño de las mariposas es muy parecido al del tapiz que es objeto del presente estudio, principalmente, en el ejemplo del Field Museum de Chicago. También se ha señalado que, en tiempos precoloniales, las mariposas podrían haberse vinculado con los mensajes de muerte o con el alma del difunto (García, 2009: 12). Tal hipótesis puede ser acertada, más aún, si se tiene en cuenta que en hoy en día las mariposas suelen vincularse con presagios de muerte en distintas regiones de los Andes. En otros objetos (textiles y cerámica) del período inca, tal vez ofrendas, aparecen también mariposas como en la chuspa inca del Ethnologisches Museum de Berlín (Inventario N. o VA 53036) (Kurella y Castro, 2013: 253) o el plato de cerámica encontrado en Machu Picchu durante la exploración de Hiram Bingham (Aguilar Callo, 2011: 51).

En la zona A1, el motivo ornitomorfo, que presenta una cabeza alargada con un gran ojo, alas desplegadas y extremidades inferiores, es más complejo de identificar. Aunque no se cuenta con mayores datos que sustenten la idea, se cree que podría relacionarse con la trasformación en ave u otro animal que ciertos sacerdotes decían lograr con la ayuda de alucinógenos, como se ha sugerido en Chavín (Burger y Salazar-Burguer, 1994).

La línea en zigzag de la zona B es un elemento frecuente en la iconografía andina desde tiempos ancestrales y es un motivo persistente en casi todos los uncus elaborados de acuerdo al patrón estándar impuesto por el sistema inca. Aparece inscrita en recuadros, en bandas o bordada en el orillo inferior de la prenda. Tal línea también es frecuente en la cerámica imperial inca, unas veces asociado al concepto de serpiente "amaru", como en una vasija "aribaloide" del MNAAHP, (Matos 1999, 136). Para la investigadora M. Frame, dicha línea es un patrón gráfico o familia de tocapu que presenta variantes y pertenece a la familia de triángulos isósceles dispuestos en hileras horizontales (2014). Según la autora se trata de un motivo presente en tejidos de varias comunidades en la actualidad y se interpreta de manera diversa. Cerca de la ciudad de Cusco suele ser llamado "puntas" y es relacionado con la cumbre de un cerro, con una península o con todas las cosas que tienen forma puntiaguda. En la comunidad Q'ero, es afín a dientes y en otros pueblos de la misma región se interpreta como río zigzagueante o sendero zigzagueante (Frame, 2014: 255).

Al centro del tapiz se ubica el motivo principal de la composición y el único proveniente del lenguaje visual occidental. Se trata de la cruz del calvario, el símbolo cristiano católico más importante que representa la Pasión y Muerte de Jesucristo en el monte Gólgota o de la "calavera" ${ }^{\text {. Este }}$ tema ha sido representado en el arte desde la Edad Media en relieves de iglesias románicas y góticas, y luego pasaría a otros soportes para volverse frecuente durante el Renacimiento y en épocas posteriores. Suele ser representado con una calavera ubicada al pie de la cruz que alude al monte Gólgota7. Tanto la forma del crucero, así como los peldaños de la cruz aluden al monte escenario del sacrificio de Jesús; sin embargo, llama la atención la presencia de dos calaveras,

6. Gólgota es una palabra aramea que significa 'calavera'. 'Calvario' es la forma latina de esa palabra.

7. En el British Museum de Londres se conserva un dibujo realizado por Miguel Ángel, escultor y pintor del Renacimiento italiano, de un Cristo en la cruz donde aparece un cráneo ubicado en la zona inferior. 
cuando lo frecuente en el tema iconográfico cristiano es la presencia de solo una de ellas. El caso citado por la antropóloga V. Gavilán, quien estudió a grupos aimaras del norte de Chile, tal vez contribuye a comprender lo sucedido. La autora narra el caso de un comunero que al encontrar en un libro de catecismo referencias al hombre, lo considera un error y corrige agregando "y mujeres" (Gavilán Vega,1996: 104). Se puede interpretar que el uso del término hombres para expresar humanidad no es aceptado por el hombre andino por considerarlo incompleto. Tal vez sucedió lo mismo con el tejedor autor del tapiz que es objeto de este estudio. Considerando lo escrito por Gavilán, es posible suponer que el tejedor incluyó una segunda calavera que representara al género femenino. Así, ambas representaciones harían referencia a toda la humanidad ${ }^{8}$.

Entonces, la iconografía del tapiz representaría la muerte y resurrección con formas tanto cristiano/católicas como andinas. Mientras que la cruz del calvario es el símbolo cristiano, las mariposas y el motivo antropomorfo (hombre-ave) podrían ser los símbolos andinos de tales conceptos durante inicios del período colonial. Sin embargo, llama la atención que aparezcan los motivos propios del lenguaje visual andino fusionados con el símbolo cristiano-católico de la cruz para transmitir el dogma de la muerte y resurrección de Jesucristo. Como se sabe, las imágenes vinculadas a creencias y ritos ancestrales fueron prohibidas en los Andes en distintos momentos. ¿Porque se recurre entonces a símbolos que aluden a la cultura y religiones que la Iglesia católica estaba buscando erradicar? Se evaluarán posibles respuestas más adelante.

\section{La manufactura andina tradicional y su relación con el tejido fino de los incas}

No solo el uso de una iconografía de origen precolonial validaría una procedencia temprana para el tapiz del MNAAHP, también los detalles técnicos confirmarían tal hipótesis. La Tabla 1 contiene un resumen del análisis técnico. ${ }^{9}$

Hay varias coincidencias entre el tapiz colonial con tocapus y los uncus de cumbi de los incas. Como se sabe, estas túnicas eran fabricadas por especialistas de acuerdo a patrones controlados por el Estado, su uso como indumentaria se reservaba a hombres de la élite y al gobernante inca, quien se encargaba de distribuirlos; se empleaban también para los oficios religiosos (Rowe, 1999). Algunos ejemplos han sido tratados desde el punto de vista de su manufactura (A. Rowe 1995-1996, 7), gracias a ello se pudo deducir que el tejido que estudiamos aquí comparte con aquellos uncus no solo el uso de las fibras textiles más finas, como el algodón y el camélido teñido, preparadas en torsiones y densidad análogas, sino también la técnica de entrecruzamiento de hilos conocida como tapiz, entre otros aspectos que trataremos más adelante. Esta técnica se caracteriza por emplear tramas parciales o discontinuas (las tramas no se desplazan en toda la extensión del tejido) que forman los diseños y cubren completamente a la urdimbre ${ }^{10}$. Los hilos van fuertemente ajustados unos a otros, de manera que resulta un tejido denso y resistente (Ramos y Blasco, 1977; Emery, 1966; D’Harcourt, 1974). Mientras más finos sean los hilos de trama y más ajustados se encuentren, la pieza será de mejor calidad, de hecho, la calidad de la tela se puede medir

Tabla 1. Información técnica básica

\begin{tabular}{|c|c|c|}
\hline Denominación & \multicolumn{2}{|c|}{ Tapiz colonial con tocapus } \\
\hline Ubicación & \multicolumn{2}{|c|}{ Museo Nacional de Arqueología, Antropología e Historia del Perú-Lima } \\
\hline Código & \multicolumn{2}{|l|}{ RT7788 } \\
\hline Procedencia & \multicolumn{2}{|c|}{ Desconocida } \\
\hline Dimensiones & \multicolumn{2}{|c|}{ Trama $376 / 383 \mathrm{~cm}$, urdimbre $300 / 311 \mathrm{~cm}$} \\
\hline \multirow[t]{2}{*}{ Materiales, torsión y densidad } & Urdimbre & $\begin{array}{l}\text { Algodón. Hilos de tres cabos. o.6-o.8 mm de diámetro. Torsión Z retorsión S, 55- } \\
65^{\circ}, 7-9 \text { hilos por } \mathrm{cm} \text {. }\end{array}$ \\
\hline & Trama & $\begin{array}{l}\text { Fibra de camélido. Hilos de dos cabos de 0.2-0.4 mm de diámetro. Torsión Z retor- } \\
\text { sión } \mathrm{S}, 10-20^{\circ}, 28-60 \text { hilos por } \mathrm{cm} \text {. }\end{array}$ \\
\hline \multirow[t]{2}{*}{ Colores } & Urdimbre & Blanco (natural) \\
\hline & Trama & $\begin{array}{l}\text { Blanco (natural), negro/marrón oscuro (natural), rojo (teñido), amarillo/ocre } \\
\text { (teñido) }\end{array}$ \\
\hline Técnica de manufactura & \multicolumn{2}{|c|}{ Tapiz ranurado, dovetail y excéntrico } \\
\hline Estado de conservación & \multicolumn{2}{|c|}{ Regular-malo } \\
\hline
\end{tabular}

8. Fue la historiadora del arte Bat-Ami Artzi quien me hizo tal observación y me proporcionó la citada fuente, por lo cual le agradezco. 9. El informe técnico fue realizado por la conservadora de textiles Yuki Seo.

10. Predominan en la pieza las variantes tapiz ranurado (ojal) y dovetail (unión de trama en la urdimbre) y el tapiz excéntrico. La técnica tapiz se ubica dentro de la clasificación de urdimbres y tramas entrelazadas como una variante de weft-faced plain weave (tejido plano cara de trama) (Emery, 1966: 78). 
por la cantidad de hilos por $\mathrm{cm}^{2}$. Así, se explica por qué el tejido de cumbi se hizo principalmente con este tipo de ligamento. Se trata de una técnica desarrollada ampliamente en el Antiguo Perú desde el Intermedio Temprano (Paracas y Nazca) y se conservan impresionantes ejemplos de uncus huari, así como incas.

El tapiz del MNAAHP ha sido realizado en una sola pieza, como varios de los uncus estandarizados, lo cual lleva a pensar que ello garantiza una mayor duración, pues se ha podido determinar que el deterioro se inicia en las uniones de los paños que forman una prenda. Los materiales (algodón y fibra de camélido) son los mismos de los uncus y la preparación de los hilos también es semejante. Las urdimbres son de algodón blanco natural de tres cabos y las tramas son de camélido de dos cabos. La torsión en ambos elementos estructurales del tejido es la misma que en las prendas imperiales: hilado en $\mathrm{Z}$ y retorsión (o plegado) en S. La densidad de hilos varía entre 7-9 urdimbres y entre 28-6o tramas por $\mathrm{cm}$, como buena parte de los uncus inca vistos por los especialistas señalados. Es decir, la densidad de hilos presente en el tapiz del MNAAHP está en el rango de los uncus del sistema textil de los incas. Aunque, existen algunos uncus extremadamente finos, como el de la colección Dumbarton Oaks, que llegan a tener entre 15-19 urdimbres por 98-108 tramas por $\mathrm{cm}$. Los colores blanco (natural), marrón oscuro-negro (natural) rojo (teñido con cochinilla) y amarillo-ocre (teñido) del tapiz son también frecuentes en los tejidos incas; la combinación del rojo y amarillo es la más común (Rowe A. P., 1995-1996: p. 9), aunque el negro y blanco fueron frecuentes (Roussakis y Salazar, 1999: 269).

Otra semejanza es la urdimbre que corre en sentido horizontal a la disposición de la pieza, que indica que el tejedor o tejedores trabajaron viendo el diseño en sentido lateral, característica presente también en las piezas incas. Por las dimensiones del tejido, el tipo de telar empleado fue el vertical, el mismo que se usó para tejer los uncus. B. Cobo describe este tipo de telares y compara la calidad del tejido de su tiempo con los de tiempos incas de la siguiente manera:

Los telares en que tejían estos cumbis, particularmente las piezas grandes para tapicería, eran diferentes de los comunes; hacíanlos de cuatro palos en forma de bastidores, y poníanlos levantados en alto arrimados a una pared, y allí iban los cumbicamayocs con muchos hilos y espacio

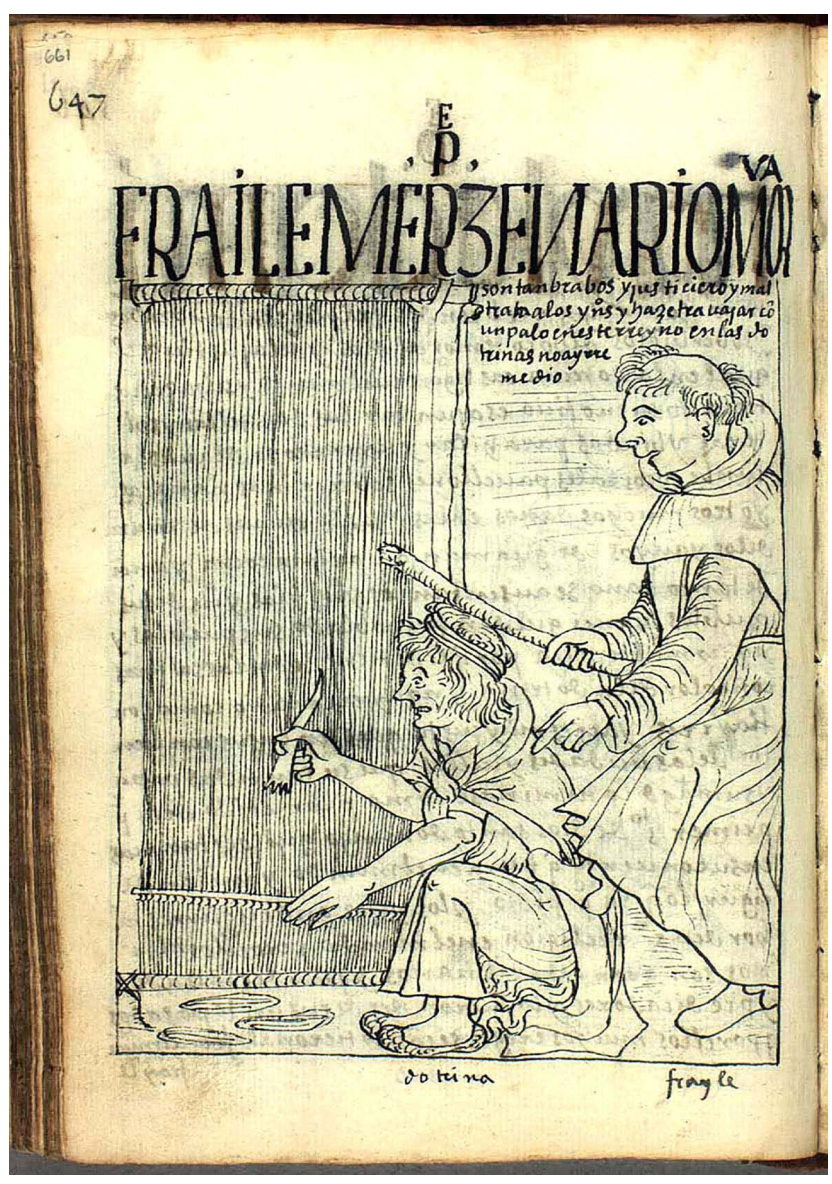

Figura 7. Fraile Merzenario Morua. Dibujo a tinta. Guamán Poma de Ayala, 2016 [1615], Royal Danish Library, GKS 2232 kvart: Guaman Poma, Nueva corónica y buen gobierno (c. 1615), pág. 647 [661].

haciendo sus labores, las cuales salían muy perfectas y acabadas, igualmente a dos haces; y el día de hoy suelen hacer reposteros de los mismos con los escudos de armas que les mandan; si bien el cumbi que ahora labran no llega con mucho a la fineza del antiguo (Cobo 1956 [1653]: 259).

Lo anotado por Cobo es relevante no solo porque describe el telar vertical, sino también porque comenta que los cumbicamayocs tejían hacia mediados del s. XVII tapices al gusto occidental, a los que Cobo llama también cumbi. De igual manera, Guamán Poma señala en varias secciones de su manuscrito piezas de tipo hispano elaboradas junto con las andinas tradicionales, que se van incorporando al repertorio textil en algunos casos a instancias de los sacerdotes de doctrina ${ }^{11}$ como se explica en un

11. «Frayle dominico: Los dichos rrebrendos frayles son tan brabos y soberbiosos, de poco temor de Dios y de la justicia, el qual en la dotrina castiga cruelmente y se haze justicia. Todo su oficio es ajuntar las donzellas y solteras y biudas para hilar y texer rropa de auasca [tejido corriente], cunbe [fino] y costales, pauellones, sobrecamas, nanacas [?] y otros muchos daños en las dichas dotrinas de Xauxa, de los Yauyos, de Guamanga, Parinacocha» (Guamán Poma, 2016 [1615]: 646 [66o]). 


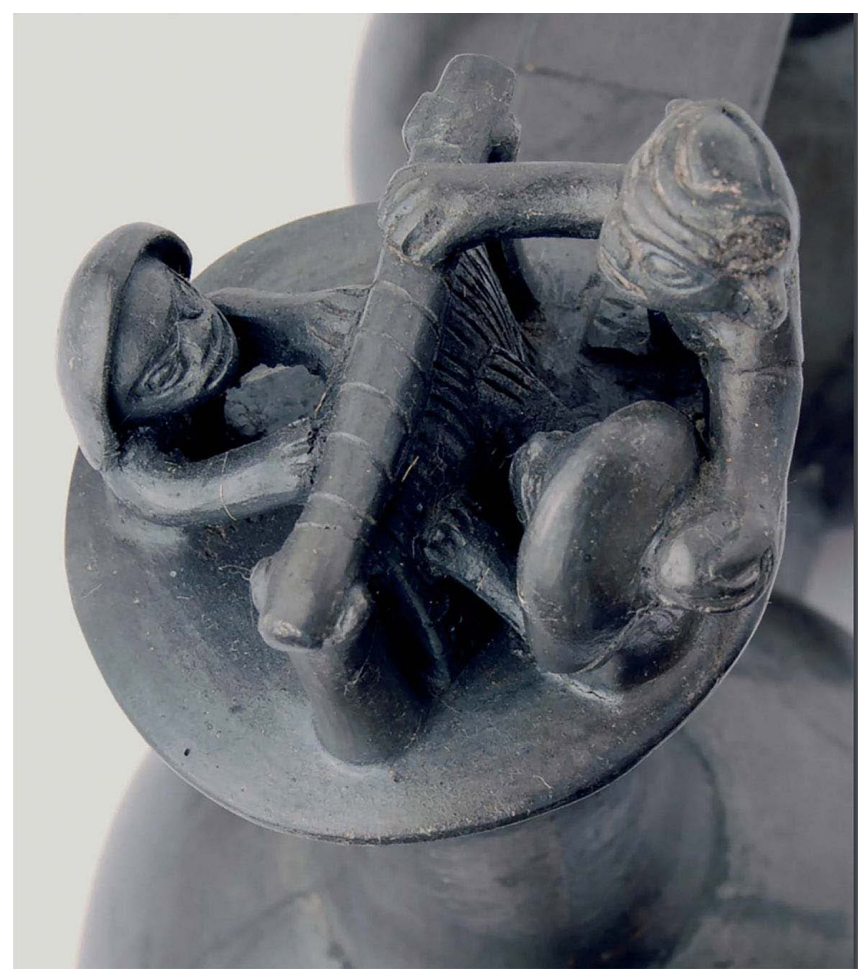

Figura 8. Detalle de vasija con escena textil. Procedencia Pachacamac. Estilo Chimú Inca R. N. 013673. Tomada de Angeles (2011: 53). Archivo Museo de sitio Pachacamac. Fotógrafo: Walter Hupiú

estudio que presentaré dentro de poco ${ }^{12}$. Aunque Cobo describe el telar vertical, Guamán Poma ofrece una representación gráfica (Figura 7) que guarda relación con el telar que aparece en una cerámica encontrada en Pachacamac de filiación chimú-inca (Figura 8) donde dos tejedores trabajan bajo supervisión. El dibujo del cronista andino también es prácticamente igual a los telares que se observan en la fotografía del equipo de Hiram Bingham tomada cerca de Macchu Picchu en 1911 (Niles 1992: 63) en la que los maestros tejedores se encuentran en plena labor realizando tapices de distintos tamaños.

Pero, no solo los materiales, la técnica, el telar y los colores son semejantes tanto en tejidos incas como en el tapiz de tocapus de esta investigación, lo es también el acabado. No existen hilos sueltos o terminaciones que no hayan quedado firmes y ocultas en la estructura del tejido. También es reversible, es decir, ambas caras del tejido se encuentran bien acabadas para ser utilizadas indistintamente. El hilado es muy delgado y parejo, salvo en algunas pocas secciones se ha identificado un grosor distinto del hilo de trama. Todo lo expuesto demuestra que los tejedores tuvieron conocimiento del sistema estandarizado impuesto por los incas para la elaboración de tejidos finos, o fueron formados en esa tradición textil.

Ciertos cambios con respecto al tejido andino ancestral se observan en la pieza colonial que se estudia. Con seguridad, dos o más tejedores trabajaron de manera simultánea, ello se deduce de los catorce tramos de labor que se ha podido identificar y en detalles, como la variedad de la densidad de hilos por $\mathrm{cm}$. Asimismo, distintos niveles de destreza se pueden encontrar en la ejecución de los diseños. Todo ello conlleva a argüir que este ejemplar fue elaborado por un grupo de tejedores dirigidos por un maestro, tal vez un cumbicamayoc con otros tejedores menos hábiles. Varios son los ejemplos de tapices coloniales que muestran distintos tramos de labor y cambios en los diseños, detalles que indicarían la intervención de más de un tejedor trabajando de manera simultánea en la misma pieza (Niles, 1992). Se ha sugerido que «los patrones de trabajo de los tapices coinciden con la interpretación de que fueron hechos por familias o pequeños grupos de trabajadores siguiendo las demandas de un recolector de impuestos, encomendero o propietario de hacienda, o para la venta» (Niles, 1992: 64).

Las diferencias con respecto a los tejidos incas se concentran en la falta de destreza de algunos de los tejedores observable en sectores como uniones de trama, que revelan descuido, detalle pocas veces visto en los uncus imperiales. La falta de una supervisión especializada sumada a la presión del nuevo comitente español son las causas probables del decaimiento de la calidad.

El estado de conservación que presenta el tapiz es de regular a malo debido a lagunas y faltantes de medianas y pequeñas proporciones (en los bordes principalmente), deshilachados, roturas y manchas. Estos deterioros han sido causados por tensión, manipulación y desgaste de fibras. Hasta el momento que observamos por última vez la pieza (noviembre de 2016) no había recibido ninguna intervención de restauración en el taller de conservación y restauración del museo. Ello ha permitido conocer cómo los usuarios del objeto prolongaron su uso. Varias zonas maltratadas han sido entretejidas (zurcidas) y parchadas en distintos momentos empleando materiales diversos como hilos de algodón, lana y otros en remiendos de distintas calidades.

\section{Usos y funciones del tapiz}

Al parecer el tapiz fue empleado en el ceremonial católico en distintos momentos del calendario religioso, tal vez en la 
Semana Santa y en las misas fúnebres, quizá como paño de púlpito o de altar, o también pudo ser usado como pieza de altar colgada en un retablo; es decir, como una herramienta o instrumento para la evangelización tlanto la pintura, la escultura y el arte en general fue parte de la estrategia de comunicación visual de la Contrarreforma.

Como se sabe, el virreinato peruano no estuvo al margen de la política religiosa de los siglos XVI y XVII, instaurada para enfrentar a las críticas de las Iglesias protestantes. Así, para adecuarse a las recomendaciones del Concilio de Trento (1545-1563), que exhortaba el uso de imágenes en la conversión de los herejes, se realizó el Segundo Concilio Limense (1567), en cuyas disposiciones se insiste también en el ornato de las iglesias y en el uso de las imágenes. Por eso, las distintas órdenes religiosas afincadas tanto en la Ciudad de los Reyes, como en el interior del país, fueron refaccionando sus casas y templos. Franciscanos, dominicos, jesuitas, entre otros, contaron con los mejores materiales y objetos de arte para engalanar sus iglesias: maderas nobles, como cedro de Nicaragua para artesonados y retablos; cerámica de revestimiento de Sevilla para zócalos y paredes y pinturas de los mejores talleres europeos, como Sevilla y Flandes. Cabe resaltar que los pintores de oficio activos en Lima eran escasos durante el período colonial temprano. Recién en el último cuarto del siglo XVI llegó el primer pintor con formación, el jesuita italiano Bernardo Bitti (Solórzano, 2012), quien es considerado el «padre de la pintura peruana virreinal» (Stastny, 2013). A falta de pintores de oficio con renombre, se contaba en cambio con muy buenos tejedores formados en la antigua tradición textil andina, a quienes seguramente se recurrió para la elaboración del material de apoyo en la tarea evangelizadora. Las imágenes tejidas se emplearían no solo para decorar los ambientes, sino que funcionarían también como vehículo de transmisión de contenidos religiosos católicos.

Los estudios de la historiadora Maya Stanfield-Mazzi coinciden con el planteamiento del uso de paños elaborados con las técnicas andinas ancestrales para el ritual religioso cristiano. Ella basándose en el análisis de documentación de archivo procedente de la sierra sur, afirma que abundan los frontales de altar elaborados con materiales y técnicas, seguramente, muy semejantes a los descritos en este estudio. Un ejemplo de relevancia es el frontal del altar principal de la iglesia de San Pedro de Juli, cuyo panel central presentaba una cruz al centro y bordes ajedrezados con recuadros en rojo y amarillo, según el inventario de objetos de la iglesia del año 156o (Stanfield-Mazzi, 2013: 44).

Uno de los aspectos más interesantes del paño, que es objeto de esta investigación, es que muestra el uso de elementos simbólicos de dos tradiciones culturales para transmitir un contenido cristiano-católico. El símbolo más importante de la fe cristiano-católica es representado acompañado de "símbolos" de la cultura andina. Cabe preguntarse ¿por qué el uso de la iconografía andina fusionada con la de la Iglesia católica? Recordemos que los símbolos vinculados con las creencias andinas ancestrales estuvieron prohibidos en distintos momentos. A raíz del movimiento mesiánico Taki Onqoy (década 156o), que anunciaba la destrucción del mundo hispano-occidental por una alianza de los dioses andinos y que promovía un retorno a la práctica de los antiguos ritos religiosos, se estableció una serie de medidas, en forma de reglas básicas para los visitadores con el fin de controlar y evitar la representación de imágenes relacionadas con las antiguas creencias:

Item, porque de la costumbre enjerida que los indios tienen de pintar ídolos y figuras de demonios y animales a quienes solían mochar, en sus tianas, vasos, báculos, paredes y edificios, mantas, camisetas, lampas y casi en todas cuantas cosas les son necesarias, parece que en alguna manera conservan su antigua idolatría, provereis, en entrando en cada repartimiento, que ningún oficial de aquí adelante, labre ni pinte las tales figuras, so graves penas, las cuales executareis en sus personas y bienes lo contrario haciendo. Y las pinturas y figuras que tuvieran en sus casas y edificios, y en demás instrumentos que buenamente y sin daño se pudieran quitar y señalareis que pongan cruces y otras insignias de xtianos en sus casas y edificios (Romero, 1924: 171).

También Cristóbal de Albornoz, quien fuera el más tenaz perseguidor en la lucha contra el "paganismo", aconsejaba destruir tanto queros como "los tejidos con un diseño de cuadros o pintados con imaginería de culebras”. Para Albornoz, estos objetos se relacionaban con la idolatría y «conjuraban recuerdos del pasado» (Cummins, 2004: 223). En una ordenanza de 1574 dirigida a la zona de Chuquisaca, el virrey Toledo de manera específica prohibió:

No se labren figuras en la ropa ni en los vasos, ni en las casas [...] por cuanto dichos naturales también adoran algún género de aves y animales y para el dicho efecto los pintan e labran en los mates que hacen para beber y de plata, y en las puertas de sus casas y los tejen en los frontales, dorseles [sic] de los altares e los pintan en las paredes de las Iglesias ${ }^{13}$. 
Como consecuencia de tales disposiciones, los andinos optaron por adecuarse a las formas de representación aceptadas y disfrazaron/ocultaron sus símbolos propios. Entonces, el tapiz de tocapus del MNAAHP pudo ser tejido antes de las disposiciones toledanas. Según T. Cummins, «Para los artistas nativos, el pretexto de la extirpación de idolatrías llevó a la desaparición de ciertos aspectos de su arte durante el último tercio del siglo XVI [...] la presentación de estas imágenes y la manera como expresaban un significado tenían que cambiar si aparecían públicamente, para que estuvieran de acuerdo con el gusto español en vez de contradecirlo» (2004: 227).

Si el tapiz fue elaborado antes de las ordenanzas del virrey Toledo, ¿por qué luego no fue destruido? Cabe considerar que, con las campañas de extirpación de las idolatrías, que se dieron con mayor intensidad en el siglo XVII, se produjo la destrucción masiva de millares de objetos considerados sagrados para la cultura andina. Sin embargo, la razón podría ser la indulgencia de la Iglesia local, pues los objetos híbridos con contenidos andinos e hispanos fueron permitidos en ciertas situaciones. Las formas andinas tradicionales se permitían siempre y cuando no se vincularan con sus antiguas creencias y, probablemente, el tapiz estudiado no fue destruido debido a que fue empleado en el contexto del culto cristiano.

La flexibilidad de la Iglesia en el Perú, que permitió iconografías híbridas, tiene antecedentes en la Iglesia europea, que luego del Concilio de Trento "estuvo lejos de mostrarse tiránica” y más bien fue "indulgente con la leyenda", al permitir temas extraídos de narraciones apócrifas de los evangelios sagrados (Mâle, 2001: 487). El extendido uso que tuvo el tapiz analizado en esta tesis, evidenciado en su desgaste, demuestra también que las disposiciones para el control de las formas andinas de representación no fueron tan estrictas en todas las regiones del Perú.

Cabe indicar también que existen otros objetos religiosos híbridos en los que se funden elementos de ambas culturas, como la cruz con tocapu del Staatliche Museen de Berlín, cuya cronología es discutida (Figura 9). Para algunos, data de los siglos XVII-XVIII (Kurella y Castro, 2013: 226), sin embargo, el destacado estudioso M. Ziólkowski afirma que podría ser del período colonial temprano (Comunicación personal, Pisac, Cusco 2014). También el uncu santo del Museo Nacional de Etnografía y Folklores de La Paz, (Figura 10a y 10b) una pequeña túnica para vestir la imagen del niño Jesús, tejida en tapiz con borde inferior de tocapus y campo central con formas geométricas, aves, símbolo mariano en el centro y también mariposas. Data de fines del s. XVI e inicios del s. XVII (Phipps, 2013: 42).

El tejido descrito en este apartado no es el único con tema religioso. Existen otros tres tapices andinos coloniales que

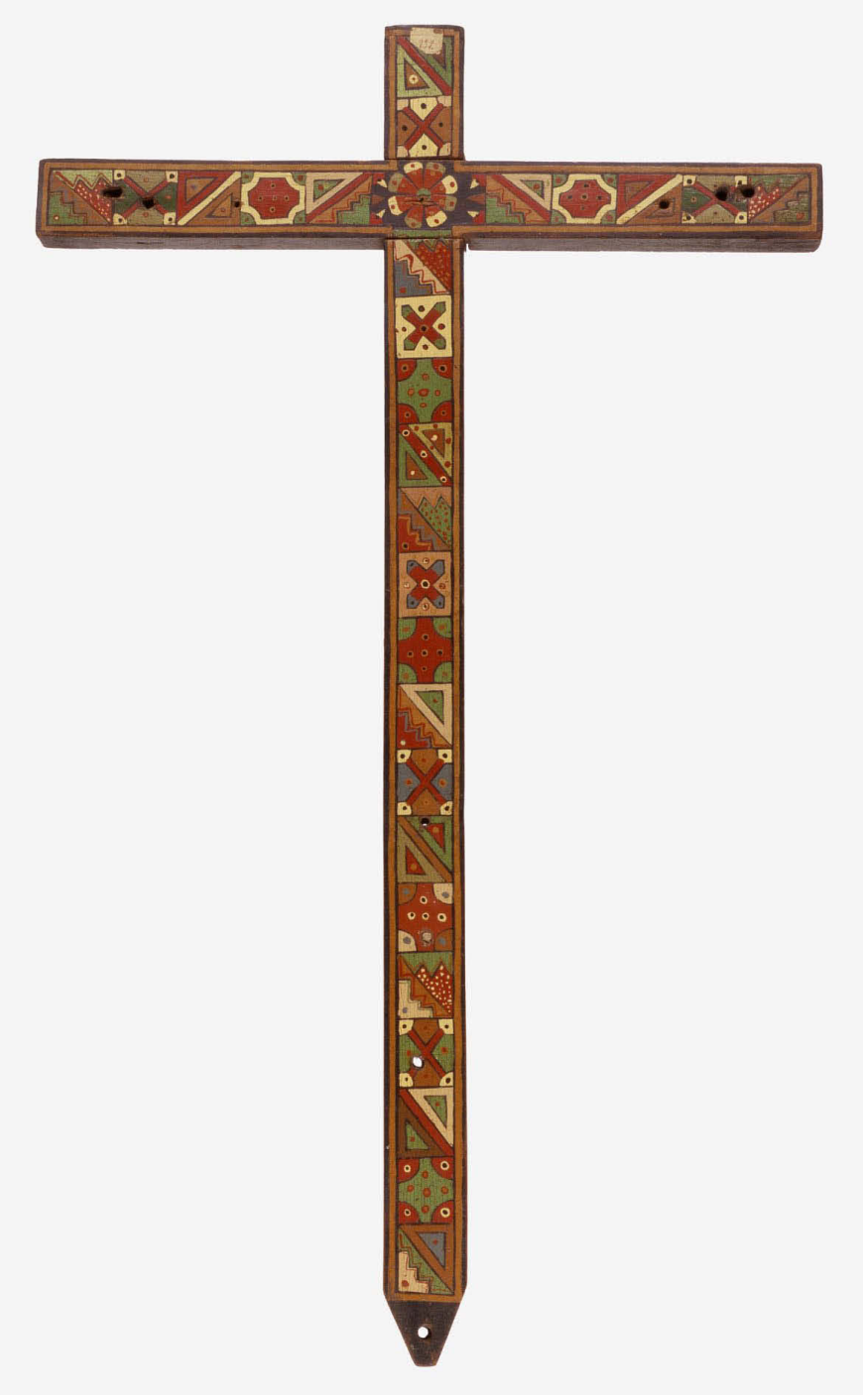

Figura 9. Cruz de madera con tocapu. Staatliche Museen zu Berlin, Ethnologisches Museum, V A 8951. Fotógrafo: Martin Franken

representan escenas del Antiguo Testamento Se trata de La creación de Eva (Círculo de Armas, Buenos Aires), El pecado original (Colección privada, Buenos Aires) y El rey David (Colección privada, La Paz) (Phipps, E., Hecht, J. y Esteras, C., 2004, p. 283, 72, 285). Al parecer todos pertenecen a la misma época y al mismo taller (Iriarte 1992). Todos han sido tejidos en la técnica de tapiz entrelazado simple con urdimbres de algodón y tramas de camélido hiladas en $Z$ y plegadas en S. Han sido datados entre fines del siglo XVI y principios del s. XVII, debido tanto a la iconografía como a los detalles técnicos y proceden probablemente de Cusco. Son tan complejos y tan finos que se ha sugerido que solo tejedores entrenados en la antigua tradición inca, o algunos de sus descendientes, pudieron haber sido los autores 


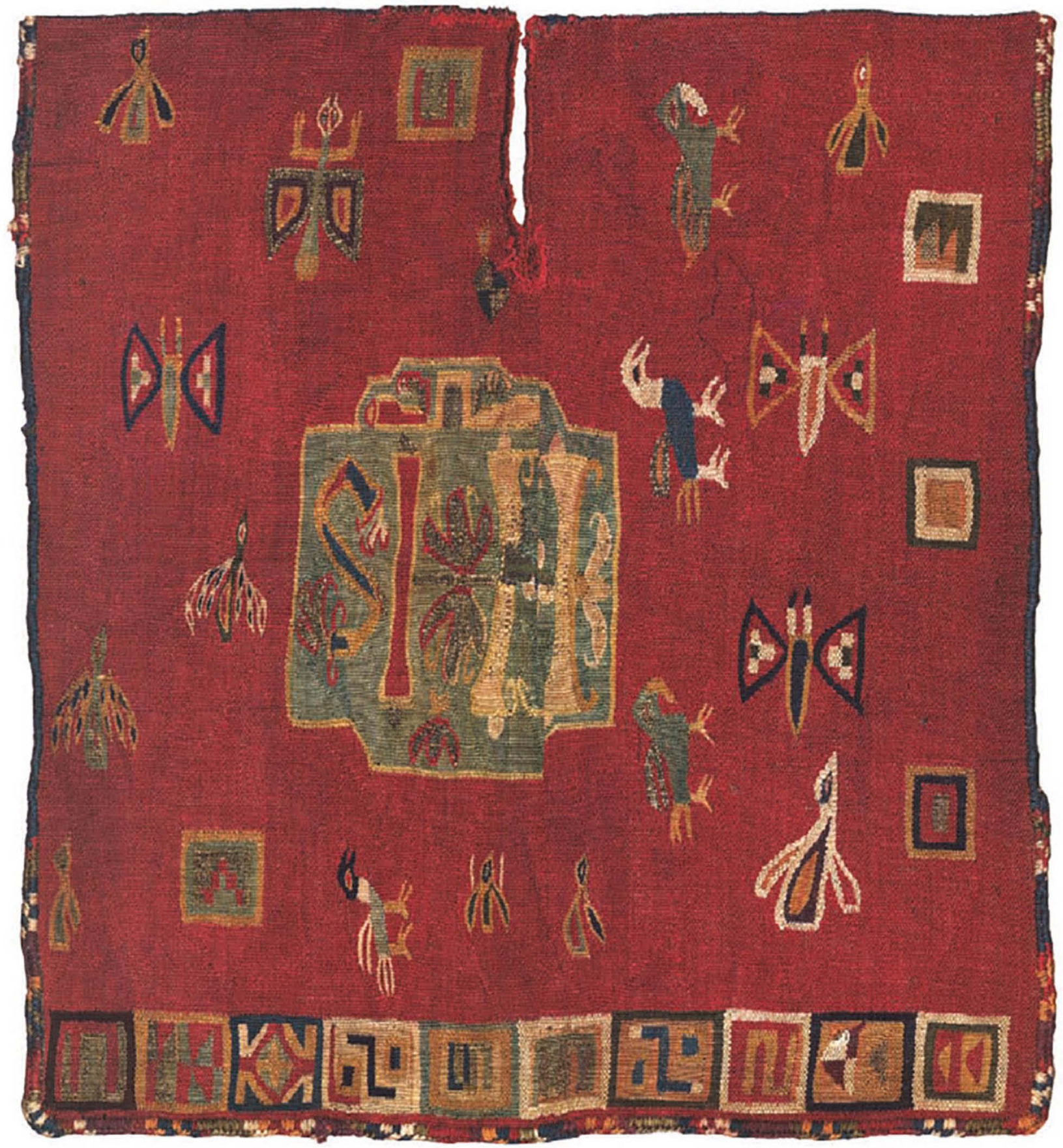

Figura 10a. Uncu santo, anverso. Fines del s. XVI e inicios del s. XVII. Museo Nacional de Etnografía y Folklores de La Paz, Bolivia. Tomado de Phipps, Hecht y Esteras (2004: 274)

(Iriarte, 2004, pp. 283,284). Coincido con la investigadora Iriarte, quien cree que fueron realizados a pedido de un comitente religioso, el cual, posiblemente, ideó la iconografía de los tapices, que habrían sido colgados en una iglesia o casa religiosa para que sirvieran de apoyo en el discurso evangelizador.
La Creación, en Postilles sur les libres de l'Ancien et du Nouveau Testament, obra de Nicolas de Lyre (127?-1349?) franciscano, exégeta y teólogo puede contribuir con la identificación de las fuentes de inspiración de los autores de la composición de los tapices con escenas bíblicas. El manuscrito que data de fines de la Edad Media contiene pequeñas 


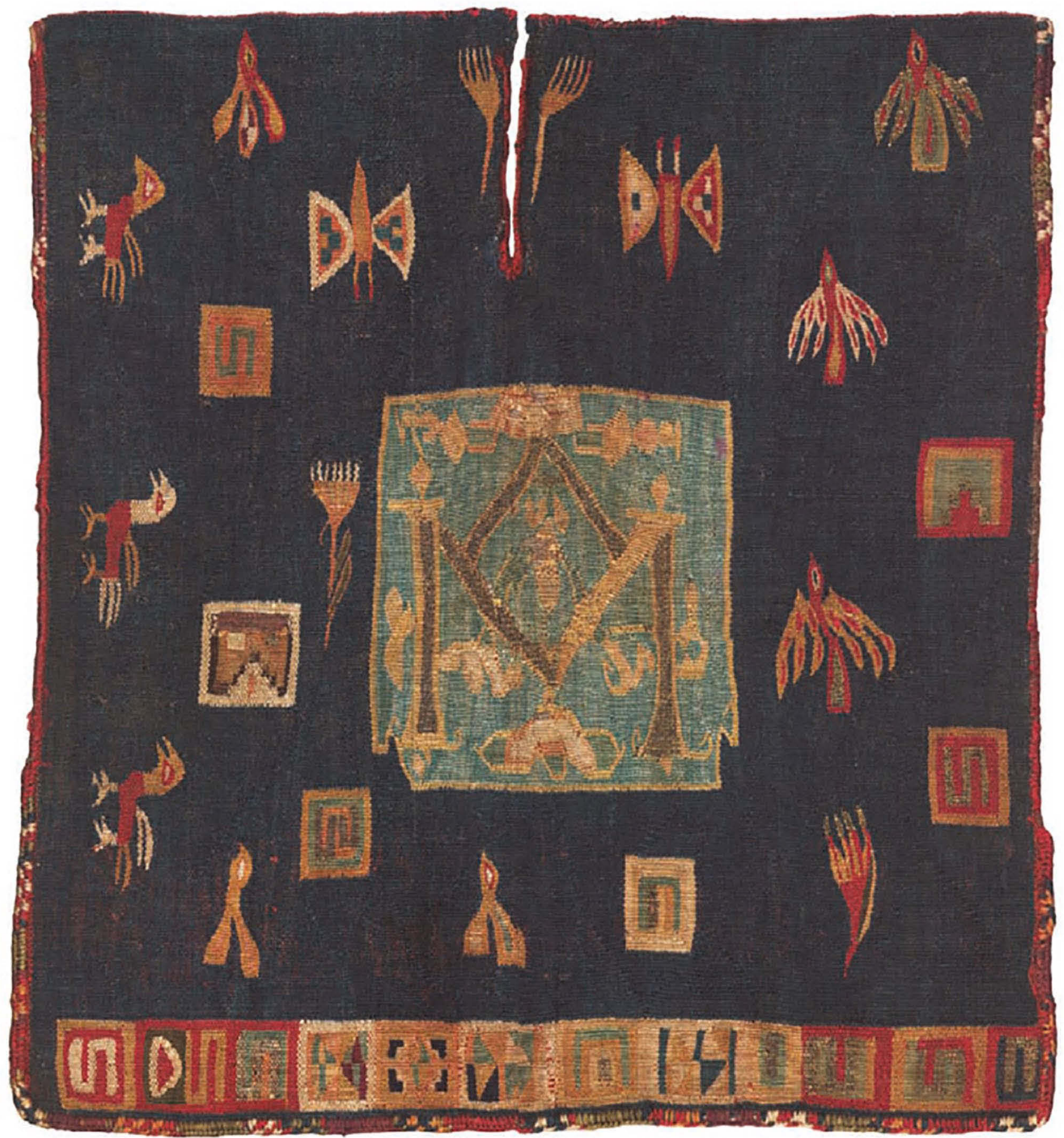

Figura 1ob. Uncu santo, reverso. Fines del s. XVI e inicios del s. XVII. Museo Nacional de Etnografía y Folklores de La Paz, Bolivia. Tomado de Phipps, Hecht y Esteras (2004: 275)

pinturas en los inicios de ciertos sectores con detalles y soluciones plásticas típicas de esa época. Es notable la composición y la disposición de los personajes rodeados por animales de la ilustración (Tesniere \& Delcourt, 2004, p. 38) que guarda estrecha relación con la composición de los personajes del tapiz La creación de Eva (donde Adán yace en el suelo recostado sobre su brazo izquierdo y desde su espalda se proyecta el cuerpo desnudo de Eva quien extiende su mano hacia la de Dios Padre). El tejedor del tapiz andino, siguiendo un modelo seguramente muy semejante a la viñeta iluminada, rodea a los personajes con animales cuadrúpedos de distinta especie, como elefante, camello, y reptiles, 
así como con flores y plantas que completan la escena de la creación bíblica de las especies y el paraíso. La autoría de la viñeta iluminada recae sobre el Maestro de la Policratica de Carlos V, quien fue un iluminador (ilustrador) activo en París, entre 1366 y 1403, lleva el nombre de la copia de dedicación de la obra traducida de Policratique de Jean de Salisbury por Denis Foullechat, realizada en 1372 (Calames 2007). La cronología de la imagen, que data de fines de la Edad Media, contribuye a entender la concepción del espacio y el tratamiento de las figuras de los tres tapices todavía lejos del lenguaje plástico renacentista.

\section{Posibles propietarios entre las principales órdenes religiosas}

Existe evidencia sobre distintas órdenes religiosas vinculadas a la confección de algún tipo de tapicería. Guamán Poma, por ejemplo, comenta sobre el mercedario M. Murúa, quien hacía tejer en su doctrina:

Este dicho Morúa fue comendador del pueblo de Yanaca de la prouincia de los Aymarays, el qual destruyyó grandemente a los yndios con el mal y daño y trauajos de ajuntar las solteras, hilar, texer y hazer cunbi [tejido fino] y de auasca [corriente], pauellón y sobrecama, uascas [soga] y frezadas y costales y de tiñir lana, amasejos de chicha y penas que le pone a los yndios de los pueblos y a los forasteros y al común de los yndios, yndias solteras, muchachos y muchachas (Guamán Poma, 2016 [1615], pág. 648 [662]).

Existen referencias de que en la zona Lupaca de Chucuito, la orden de Santo Domingo controló durante parte del siglo XVI la producción de tapices (Gisbert, Arze y Cajías, 1992: 29) y que los religiosos de la Compañía de Jesús que asumieron las doctrinas dejadas por los dominicos en el altiplano, establecieron talleres de tapices en Chile bajo la dirección de tejedores flamencos; sin embargo, nosotros no encontramos el sustento documental que corrobore tal información.

Los propietarios originales del tapiz estudiado pudieron ser franciscanos por la especial relación de la Orden con la devoción a la Santa Cruz, que tiene su origen en la predilección del santo fundador por la oración y la meditación frente al crucifijo ${ }^{14}$. San Francisco aconsejaba a los primeros frailes relegar los libros eclesiásticos para usar "el libro de la Cruz de Cristo" y orar delante del Crucifijo, observándolo fijamente en sus distintos aspectos. La difusión del culto a la cruz no solo fue especialmente predicada por los frailes franciscanos, sino que también fue representada en infinidad de motivos iconográficos (Sanchez, 2010). Se sabe también que el Vía Crucis, parte del ritual de la Semana Santa, fue difundido por la Orden, aunque antiguamente se pensaba que había sido instaurada por los franciscanos para honrar especialmente la pasión del Salvador (Barbier de Montault, 1898: 138,139).

Existen tres tapices vinculados con certeza a esta orden religiosa. Estos presentan cráneos con tibias cruzadas y las cinco llagas de Cristo, así como el emblemático diseño identificado con los estigmas del santo fundador. Proceden de la Sierra sur (uno de Cusco y dos de Arequipa), datan de fines del s. XVI e inicios del XVII, y fueron ejecutados en fibras locales por tejedores andinos que siguieron, probablemente, un mismo modelo (Phipps, Hecht y Esteras, 2004: 230, 231). Además, se ha sugerido que pudieron ser empleados como ornamento de los altares en servicios fúnebres o durante las celebraciones de la Semana Santa. Estos ejemplos destacan no solo por la destreza de los andinos en la ejecución de diseños foráneos, sino también por el colorido que se ha mantenido a pesar de los años.

Varios detalles llevan a pensar que el tapiz del MNAAHP procede también de algún lugar de la sierra sur. Saber en cuál de las iglesias se encontraba y cuál de los retablos decoraba es sumamente complicado; sin embargo, es posible plantear que proviene de alguna localidad de esta zona con mayoritaria población indígena. El clima también pudo haber favorecido a su conservación, así como se conservaron los tejidos citados con colores aún brillantes. Dado que los incas controlaron mejor el sistema del tejido en esa zona, es posible suponer que la tradición perduró allí por más tiempo.

Para concluir este acápite, conviene sintetizar algunos de los principales argumentos que se han vertido párrafos arriba. Primero, el estudio técnico e iconográfico del tapiz con tocapus del MNAAHP permite afirmar que tanto las técnicas textiles incaicas, así como sus símbolos continuaron vigentes mucho después de la conquista: el uso de las fibras locales, la tecnología ancestral y la iconografía, revelan pues una continuidad de la tradición textil andina. Segundo, el tapiz resultado de la tradición textil andina frente a la influencia hispana se convirtió en la pieza textil más valiosa y compleja, y llegó a cumplir distintos roles en las sociedades del período colonial temprano. Tercero, de lo evidenciado se propone una posible cronología temprana para el tapiz en cuestión, que puede datar del último cuarto del siglo XVI o de inicios del siglo XVII. El predominio de características del tejido andino ancestral revela que

14. El siguiente párrafo explica uno de los episodios más importantes en la conversión del santo: "El joven Francisco se encontraba orando ante el Crucificado de San Damiano, cuando escucha la voz de Dios que le ordena «Francisco vete para mi casa que, como ves, se viene del todo al suelo»". Settis, S. (1979), citado por Fraga Sampedro, M. (2003). Un calvario peculiar: el franciscano orante al pie de la cruz. Quintana, 2. 
tal vez fue tejido por cumbicamayocs, quienes continuaron con su labor décadas después de la conquista, o por tejedores entrenados en la antigua tradición textil. La calidad de la manufactura del tejido analizado no es la misma que la de los uncus incas imperiales. Hay cierto decaimiento de la misma, seguramente, debido a la intervención de varios tejedores con distintos niveles de dominio técnico y experiencia o, probablemente, por la falta de una supervisión especializada. Sin embargo, puede considerarse entre los objetos textiles más finos, complejos y valiosos del período colonial temprano.

Finalmente, se considera que el uso litúrgico fue una de las principales funciones que tuvo y, por ello, probablemente, las mayores órdenes religiosas, como franciscanos, mercedarios, dominicos y jesuitas, fueron los comitentes y propietarios originales. Debido a la escasez de pintores de renombre, es posible que la Iglesia recurriera a tejedores para la elaboración de paños de pared con temática religiosa. Así, el tapiz andino se convirtió en vehículo de apoyo para la transmisión del credo católico.

\section{Referencias}

Aguilar Callo, Víctor R.

2011 Machu Picchu: Catálogo de la colección. Editado por Yale, Ministerio de Relaciones Exteriores del Perú, United States of American Embassy, Universidad Nacional de San Antonio Abad de Cusco. Lima.

Barbier de Montault, Xavier.

1898 Traité D’Iconographie Chrétienne. Paris: Societé de Libraire Ecclésiastique et Religieuse, 1898.

Calames.

2007 Postilles sur les livres de l'Ancien et du Nouveau Testament. http://www.calames.abes.fr/pub/ms/ BSGA10061 (accedido 2019. 20 de abril)

Cobo, Bernabé

1956 [1653] Historia del Nuevo Mundo. Vol. II, de Obras del P. Bernabé Cobo, de Francisco Mateos. Madrid: Atlas.

Cummins, Thomas

2004 Brindis con el Inca: la abstracción andina y las imágenes coloniales de los queros. Lima: Universidad Nacional Mayor de San Marcos Fondo Editorial.

2014 El tocapu: el nudo gordiano en los Andes. En C. Arellano H., Sistemas de notación inca: Quipu y Tocapu. Lima: Ministerio de Cultura.

Emery, Irene

1966 The Primary Structures of Fabrics and Illustrated Classification. Washington D.C.: The Textile Museum.
De Lyre, Nicolas (s. f.).

Postilles sur les livres de l'Ancien et du Nouveau Testament. En Calames: Online catalogue of archives and manuscripts in French University and Research libraries. Recuperado de http://www.calames.abes.fr/ pub/\#details?id=BSGA10061

Frame, Mary

2014 «Tukapu, un código gráfico de los inkas.» En Sistemas de notación inca: Quipu y Tocapu, de Carmen Arellano Hoffman. Lima: Ministerio de Cultura.

García, María

2009 «El mundo de los muertos en la cosmovisión centroandina» Gaceta de Antropología.

Gavilán Vega, Vivian

1996 «Mujeres y hombres en Isluga y Cariquima: una aproximación a las relaciones de género entre los aymara del norte de Chile. Versión preliminar.» Tesis, Maestría en Antropología. Facultad Latinoamericana de Ciencias Sociales- Sede Ecuador.

Gisbert, Teresa, Arze, Silvia y M. Cajías

1992 Arte textil y mundo andino. Buenos Aires: Tipográfica Editora Argentina.

González Holguín, D.

1989 [16o8]) Vocabulario de la lengua general de todo el Peru llamada lengua qquichua o del Inca. Lima: UNMSM

Iriarte, Isabel

1992 «Tapices con escenas bíblicas del Perú colonial.» Revista Andina, $\mathrm{n}^{\circ}$ 10(1) (1992): 80-105.

2004 «The Creation of Eva \& King David» The colonial Andes: tapestries and silverwork, 1530-1830, Phipps, Elena; Hecht, Johana y Cristina Esteras, 283,284. New York: The Metropolitan Museum of Art, Yale University Press.

Kurella, Doris y Castro, Inés

2013 Könige der Anden. Stuttgart: Linden Museum, Staatliches Museum für Völkerkunde.

Mâle, Emile

2001 El arte religioso de la Contrarreforma. Madrid: Ediciones Encuentro S.A.

Matos, Ramiro

1999 «La Cerámica Inca.» En Los Incas Arte y Símbolos, de Carmen Arellano, y otros, 109-166. Lima: Colección arte y tesoros del Perú, Banco de Crédito del Perú.

Niles, Susan A.

1992 «Artist and Empire in Inca and Colonial Textiles» To Weave for the Sun. Ancient Andean Textiles in the $\mathrm{Mu}$ seum of Fine Arts, Boston, de Rebecca Stone-Miller, 50-66. Boston, Massachusetts: Thames and Hudson. 
Phipps, Elena

2013 «The Iberian globe. Textile traditions and trade in Latin America.» En Interwoven Globe. The Worldwide Textile Trade, 1500-180o, de Peck Amelia (Ed.), 2845. New York: The Metropolitan Museum of Art.

Phipps, Elena, Hecht, Johanna y Esteras, Cristina

2004 The Colonial Andes. Tapestries and Silverwork. New York: The Metropolitan Museum of Art, Yale University Press.

Romero, Carlos Alberto (Prol.)

1924 «Libro de la visita general del Virrey Don Francisco de Toledo (1570 - 1575).» Revista Histórica 7 (1924): 113-216.

Rosario, Noemí

1999 Tintes en el Perú prehispánico, virreinal y republicano. En Tejidos milenarios del Perú. Lima: AFP Integra, Wiese Aetna.

Roussakis, Vuka y Lucy Salazar

1999 Tejidos y tejedores del Tahuantinsuyo. En F. Pease G.Y, C. Morris, J. Santillana, R. Matos, P. Carcedo de Mufarech, C. Arellano, ... L. Vetter Parodi, Los incas, arte y símbolos (págs. 263-297). Lima: Banco de Crédito del Perú.

Rowe, Ann Pollard

1995-1996 «Inca Weaving and Costume» The Textile Museum Journal, 1995-1996: 5-53.

1995-1996 «Technical Features of Inca Tapestry Tunics » Textile Museum Journal, 1995-1996: 5-28.
Rowe, John

1999 «Estandarización de las técnicas de tapiz Inca» En Tejidos milenarios del Perú, 571-664. Lima.

Sanchez, José

2010 «La cruz como ícono protector en los espacios de tránsito.» Estudios del patrimonio cultural. http:// campaners.com/php/textos.php?text=1366. (último acceso: setiembre de 2016).

Solórzano Gonzales, Mónica

2012 La coronacion de la Virgen de Bernardo Bitti en el arte peruano colonial. Tesis para optar el grado de Magíster. Pontificia Universidad Católica del Perú.

Stanfield-Mazzi, Maya

2013 Object and Apparition. Envisioning the Christian Divine in the Colonial Andes. Tucson: The University of Arizona Press.

Stastny, Francisco

2013 Estudios de Arte Colonial. Lima: Instituto Francés de Estudios Andinos, Museo de Arte de Lima.

Tesnière, Marie-Hélène y Delcourt, Thierry

2004 Bestiaire du Moyen Áge. Paris: Somogy editions d'art. 